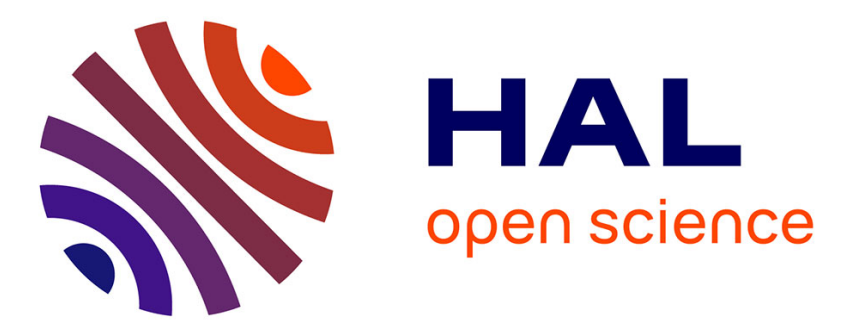

\title{
Interactions of ammonium-smectite with volatile organic compounds from leachates
}

\author{
Mathieu Gautier, Fabrice Muller, Lydie Le Forestier
}

\section{To cite this version:}

Mathieu Gautier, Fabrice Muller, Lydie Le Forestier. Interactions of ammonium-smectite with volatile organic compounds from leachates. Clay Minerals, 2017, 52, pp.143 - 159. 10.1180/claymin.2017.052.1.10 . insu-01508689

\section{HAL Id: insu-01508689 \\ https://hal-insu.archives-ouvertes.fr/insu-01508689}

Submitted on 14 Apr 2017

HAL is a multi-disciplinary open access archive for the deposit and dissemination of scientific research documents, whether they are published or not. The documents may come from teaching and research institutions in France or abroad, or from public or private research centers.
L'archive ouverte pluridisciplinaire HAL, est destinée au dépôt et à la diffusion de documents scientifiques de niveau recherche, publiés ou non, émanant des établissements d'enseignement et de recherche français ou étrangers, des laboratoires publics ou privés.

\section{(이)(\$)}

Distributed under a Creative Commons Attribution - NonCommercial - NoDerivatives| 4.0 


\title{
Interactions of ammonium-smectite with volatile organic compounds from leachates
}

\author{
Mathieu GAUTIER, Fabrice MULLER, Lydie LE \\ FORESTIER
}

\section{$\rightarrow$ To cite this version:}

M. Gautier, F. Muller, L. Le Forestier. Interactions of ammoniumsmectite with volatile organic compounds from leachates. Clay Minerals, 52, 143-158.

DOI: 10.1180/claymin.2017.052.1.10

Please contact the corresponding author if you are interested by a copy of the article published in the journal. 
Interactions of ammonium-smectite with volatile organic compounds from leachates

Authors

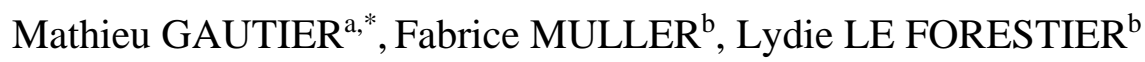

Address

${ }^{\text {a } U n i v ~ L y o n, ~ I N S A ~ L y o n, ~ D E E P ~(D e ́ c h e t s ~ E a u x ~ E n v i r o n n e m e n t ~ P o l l u t i o n s ~-~ W a s t e s ~ W a t e r ~}$ Environment Pollutions), EA7429, 69621 Villeurbanne Cedex, France.

$\underline{\text { mathieu.gautier@insa-lyon.fr }}$

${ }^{\mathrm{b}}$ Institut des Sciences de la Terre d'Orléans (ISTO), Université d'Orléans - CNRS :

UMR7327 - INSU - BRGM, 1A Rue de la Férollerie, 45071 Orléans Cedex 2, France,

fabrice.muller@univ-orleans.fr, lydie.leforestier@univ-orleans.fr

* Corresponding author

E-mail address: mathieu.gautier@insa-lyon.fr

Tel: +33472438348 


\begin{abstract}
The percolation of water through waste landfills produces leachates with high ammonium concentrations which can generate ammonium-exchanged clays within geochemical barriers. These leachates also contain several volatile organic compounds (VOCs) that can interact with the clay barrier. The aim of this study was to characterize the sorption of eight shortchain VOCs (acetonitrile, methyl tert-butyl ether, dichloromethane, benzene, phenol, ethanol, acetone, and aniline) on ammonium-smectite, and to identify their sorption mechanisms. The treated samples were characterized by carbon and nitrogen elemental analysis, infrared spectroscopy, powder X-ray diffraction, and thermo-gravimetric analyses. For acetonitrile, methyl tert-butyl ether, dichloromethane, and benzene, no sorption was detected. Phenol, ethanol, and acetone were very weakly sorbed, through Van der Waals interactions. Aniline molecules were strongly sorbed on ammonium-smectite mainly with hydrogen bonds between aniline and interfoliar water molecules. However, aniline sorption decreased the hydrophilic character of the ammonium-smectite, which may increase the permeability of the clay barrier.
\end{abstract}

Keywords: ammonium, aniline, clay barrier, infrared spectroscopy, montmorillonite, shortchain, sorption, volatile organic compounds, waste landfill, FTIR. 


\section{INTRODUCTION}

In $2013,30 \%$ and $53 \%$ of municipal waste was landfilled in Europe (Eurostat, 2015) and the US (EPA, 2015), respectively. The percolation of water through waste landfills, together with the degradation of wastes, produces leachates with high amounts of pollutants. Clay barriers are used in the bottom of these sites to mitigate any pollution in the soil and groundwater. Smectites are mainly selected due to their strong adsorption properties, their low permeability after compaction, their expansion capacity, and their high cation exchange capacity (CEC). The physicochemical composition of the leachates is strongly influenced by the nature of the buried wastes and the age of the site. A young landfill ( $<5$ years old) produces biodegradable acidic leachates $(4.5<\mathrm{pH}<6.5)$, a midlle-age landfill (5-10 years) is characterized by intermediate neutral leachates $(6.5<\mathrm{pH}<7.5)$, whereas an old landfill ( $>10$ years) is identified by stabilized basic leachates $(7.5<\mathrm{pH}<9)$ (Ghayaza et al., 2011). Leachates are highly loaded with cations, organic matter, inorganic salts, adsorbable halogenated organics, and heavy metals. Among the cations, ammonium, which is mainly produced by bacterial degradation, is present in excess (Lo, 1996; Kruempelbeck \& Ehrig, 1999; Kjeldsen et al., 2002; Öman \& Junestedt, 2008; Van Nooten et al., 2008). Ammonium concentrations in leachates vary from 4.2 to $870 \mathrm{mg} \mathrm{L}^{-1}$ in 12 Swedish municipal landfills (Öman \& Junestedt, 2008), and ammonium is expected to be present in high concentrations (>100 $\left.\mathrm{mg} \mathrm{L}^{-1}\right)$ in leachates for decades (Christensen et al., 2001; Renou et al., 2008). A natural cationic exchange can thus be anticipated in the clay barrier between the original exchangeable cations (mainly $\mathrm{Na}^{+}$and $\mathrm{Ca}^{2+}$ ) and $\mathrm{NH}_{4}^{+}$, reducing the hydrophilic character of the starting clay barrier (Pironon et al, 2003; Gautier et al, 2010). A study dedicated to ammonium-exchanged clay must then be conducted to investigate this specific interaction with leachates. 
In fact, leachate interactions with clay liners are probably far more complicated due to cosorption, formation of organoclays (due to the occurrence of proteins, amino acids, humic materials, and other organic compounds in household wastes), and other chemical processes. The sorption and the degradation of organic pollutants in the clay liner materials can also increase the chemical attenuation of organic pollutants in leachates (Bright et al., 2010). The present study focusses only on ammonium-exchanged clay, which simulates the possible evolution of the clay liner after interaction with landfill leachates. In addition to the waste landfill context, the study of $\mathrm{NH}_{4}{ }^{+}$intercalation has particular importance in other environmental issues. For example, ammonium concentrations up to $40 \mathrm{mg} / \mathrm{L}$ were regularly found in domestic wastewater (Kim et al., 2014; Kim et al., 2015; Paing et al., 2015) and even higher in farm effluent (Bolan et al., 2004; Bouwman et al., 2013). Clays can be used to remove ammonium from aqueous solution (Çelik et al., 2001; Eturki et al., 2012; Zadinelo et al., 2015). Moreover, ammonium-smectite interaction plays a key role in better understanding sedimentary rocks (Mingram \& Bräuer, 2001; Gieskes \& Mahn, 2007), silicates from the Earth's mantle (Watenphul et al., 2009), and meteorite matrices (Bishop et al., 2002; Pizzarello et al., 2012).

Landfill leachates contain large amounts of volatile organic compounds (VOCs) identified as individual pollutants, such as aromatic hydrocarbons, halogenated hydrocarbons, and phenol (Jensen \& Christensen, 1999; Kjeldsen \& Christophersen, 1999; Christensen et al., 2001; Öman \& Junestedt, 2008). Biodegradation, which occurs during anaerobic digestion, degrades organic pollutants and transforms long-chain molecules into shorter-chain molecules (Öman $\&$ Junestedt, 2008). Several authors have studied the diffusive transport in aqueous phase of VOCs through natural clays or geosynthetic clay liners (Myrand et al., 1992; Kowalska et al., 1994; Edil, 2003; Lake \& Rowe, 2004). These studies highlighted that the diffusion may play an important role in transport of VOCs through the clay barriers and that much more research 
is needed on the sorption and reaction of clays and organic pollutants to meet the future environmental challenges. Amongst VOCs, experimental sorption studies with smectites were performed on methyl tert-butyl ether (MTBE) (Sim et al., 2009), phenol (Janík et al., 2013), ethanol (Clausen, 2013), acetone (Amarasinghe et al., 2009), dichloromethane and benzene (Lake \& Rowe, 2005), and aniline (Mohammed-Azizi et al., 2011; Vasudevan et al., 2013). However, none of these studies were conducted on ammonium-exchanged clays. To our knowledge, only Gautier et al. (2009) have investigated the interaction of ammonium-clay with VOCs, in the case of low-molecular-weight carboxylic acids. They showed a cationic exchange of $\mathrm{NH}_{4}{ }^{+}$to $\mathrm{H}_{3} \mathrm{O}^{+}$with all the studied acids and a partial exchange to $\mathrm{Al}^{3+}$ only with chloroacetic and oxalic acids for which adsorption of molecules on the clay sample occurs mainly through H-bonding with the cation. Oxalic acid was found intercalated in the interlayer space.

This study aims to characterize the sorption of eight short-chain VOCs (acetonitrile, MTBE, dichloromethane, benzene, phenol, ethanol, acetone, and aniline) on ammonium-smectite after drying, and to identify their sorption mechanisms. These eight VOCs are common in landfill leachates and represent a range of functional groups (nitrile, ether, halogenated aliphatic hydrocarbon, aromatic hydrocarbon, aliphatic alcohol, aliphatic cetone, and aromatic amine, respectively). We ensured that the pHs of the organic solutions were in the order of those in landfills. Their values corresponded to the $\mathrm{pH}$ existing in young and medium-aged landfills. This study was performed on a wide range of VOC concentrations above the concentrations measured in landfill leachates. The choice of high VOC concentrations made it possible to emphasize the sorption of VOCs on ammonium-smectite, in order to determine the main sorption mechanisms. 


\section{MATERIALS AND METHODS}

\subsection{Ammonium-smectite preparation}

The smectite sample used for this study was SWy-2 Wyoming montmorillonite (Crook County, Wyoming, United States) supplied by the Source Clays Repository of the Clay Minerals Society. The impurities identified as quartz, feldspar, gypsum, mica, and illite in the untreated smectite sample represented $5 \mathrm{wt} \%$ after purification by $<2 \mu \mathrm{m}$ size separation (Chipera \& Bish, 2001). The structural formula of the $<2 \mu \mathrm{m}$ size fraction obtained from the chemical analysis (Gautier et al., 2010) is:

$\left(\mathrm{Ca} 0.13 \mathrm{Na} 0.34 \mathrm{~K}_{0.03}\right)\left[\mathrm{Al}_{3.04} \mathrm{Fe}(\mathrm{III})_{0.41} \mathrm{Mg}_{0.49} \mathrm{Ti}_{0.01}\right]\left[\mathrm{Si}_{7.98} \mathrm{Al}_{0.02}\right] \mathrm{O}_{20}(\mathrm{OH})_{4}$. Approximately $2 \mathrm{~g}$ of the Wyoming montmorillonite were poured into a Nalgene centrifuge tube and mixed with 50 $\mathrm{mL}$ of $1 \mathrm{M}$ ammonium chloride solution (Fisher Scientific, Normapur). The sample was rotated on a SRT1 Stuart Scientific roller mixer for $12 \mathrm{~h}$. After centrifugation at $2795 \mathrm{~g}$ for 5 $\mathrm{mn}$, the supernatant chloride solution was removed and the tube was refilled with a fresh $1 \mathrm{M}$ $\mathrm{NH}_{4} \mathrm{Cl}$ solution. This process was repeated five times. The sample was then introduced in a dialysis membrane tubing and placed in deionized water to remove chlorides. The water was changed daily until the disappearance of chlorides $\left(\mathrm{AgNO}_{3}\right.$ test $)$. After dialysis and decantation, the $<2 \mu \mathrm{m}$ size fraction of ammonium-smectite was extracted, dried and finely hand ground in an agate mortar. Particle-size separations are based on Stokes's law. The detailed protocol is given is given by Moore \& Reynolds (1997).

\subsection{Sorption experiments}

The organic solutions (Table 1) were prepared from mixtures of reagent-grade organic compounds (Fisher Scientific, Normapur) in deionised water (milli-Q/18.2 $\mathrm{M} \Omega \mathrm{cm}^{-1}$ ). Three 
Table 1: Physico-chemical characteristics of the selected landfill leachate contaminants.

\begin{tabular}{|c|c|c|c|c|c|}
\hline Compound & $\begin{array}{l}\text { Functional } \\
\text { group }\end{array}$ & Formula & $\mathrm{pKa}$ & $\begin{array}{c}\text { Density at } \\
20^{\circ} \mathrm{C}\left(\mathrm{g} / \mathrm{cm}^{3}\right)\end{array}$ & $\begin{array}{c}\text { Solubility in } \\
\text { water at } 20^{\circ} \mathrm{C}\end{array}$ \\
\hline $\begin{array}{c}\text { Water } \\
\mathrm{H}_{2} \mathrm{O}\end{array}$ & & $\mathrm{H}-\mathrm{O}-\mathrm{H}$ & 15.74 & 1.00 & 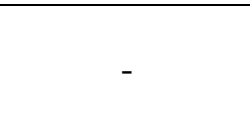 \\
\hline $\begin{array}{l}\text { Acetonitrile } \\
\qquad \mathrm{C}_{2} \mathrm{H}_{3} \mathrm{~N}\end{array}$ & Nitrile & & 25 & 0.79 & soluble \\
\hline $\begin{array}{l}\text { Methyl-tert- } \\
\text { butyl-ether } \\
\mathrm{C}_{5} \mathrm{H}_{12} \mathrm{O}\end{array}$ & Ether & & - & 0.74 & $\begin{array}{c}42 \mathrm{~g} \mathrm{~L}^{-1} \\
0.476 \mathrm{~mol} \mathrm{~L}^{-1}\end{array}$ \\
\hline $\begin{array}{l}\text { Dichloromethane } \\
\qquad \mathrm{CH}_{2} \mathrm{Cl}_{2}\end{array}$ & $\begin{array}{l}\text { Halogenated } \\
\text { aliphatic } \\
\text { hydrocarbon }\end{array}$ & & - & 1.33 & $\begin{array}{c}17.6 \mathrm{~g} \mathrm{~L}^{-1} \\
0.207 \mathrm{~mol} \mathrm{~L}^{-1}\end{array}$ \\
\hline $\begin{array}{c}\text { Benzene } \\
\mathrm{C}_{6} \mathrm{H}_{6}\end{array}$ & $\begin{array}{c}\text { Aromatic } \\
\text { hydrocarbon }\end{array}$ & & 43 & 0.88 & $\begin{array}{c}1.77 \mathrm{~g} \mathrm{~L}^{-1} \\
0.023 \mathrm{~mol} \mathrm{~L}^{-1}\end{array}$ \\
\hline $\begin{array}{l}\text { Phenol } \\
\mathrm{C}_{6} \mathrm{H}_{6} \mathrm{O}\end{array}$ & $\begin{array}{l}\text { Aromatic } \\
\text { alcohol }\end{array}$ & & 9.95 & 1.07 & $\begin{array}{c}70 \mathrm{~g} \mathrm{~L}^{-1} \\
0.74 \mathrm{~mol} \mathrm{~L}^{-1}\end{array}$ \\
\hline $\begin{array}{l}\text { Ethanol } \\
\mathrm{C}_{2} \mathrm{H}_{6} \mathrm{O}\end{array}$ & $\begin{array}{l}\text { Aliphatic } \\
\text { alcohol }\end{array}$ & & 16 & 0.79 & soluble \\
\hline $\begin{array}{l}\text { Acetone } \\
\mathrm{C}_{3} \mathrm{H}_{6} \mathrm{O}\end{array}$ & $\begin{array}{l}\text { Aliphatic } \\
\text { ketone }\end{array}$ & & 19.3 & 0.79 & soluble \\
\hline $\begin{array}{l}\text { Aniline } \\
\mathrm{C}_{6} \mathrm{H}_{7} \mathrm{~N}\end{array}$ & $\begin{array}{l}\text { Aromatic } \\
\text { amine }\end{array}$ & & 4.6 & 1.02 & $\begin{array}{c}34 \mathrm{~g} \mathrm{~L}^{-1} \\
0.365 \mathrm{~mol} \mathrm{~L}^{-1}\end{array}$ \\
\hline
\end{tabular}

concentrations were chosen for each organic molecule: a relatively low concentration $(0.01$ mol $\mathrm{L}^{-1}$ ), a moderate concentration directly dependent on the solubility limit of the molecule, and the pure liquid. Phenol, which is available in solid form, was only studied at the $0.01 \mathrm{~mol}$ $\mathrm{L}^{-1}$ concentration and for the saturated solution (about $0.7 \mathrm{~mol} \mathrm{~L}^{-1}$ ). For each batch experiment, a mass of $200 \mathrm{mg}$ of finely dispersed $<2 \mu \mathrm{m}$ ammonium-smectite was introduced 
in centrifuge tubes and rotated at room temperature in $20 \mathrm{~mL}$ of distilled water or in the organic solutions. No buffer was used. After seven days, the solution was recovered by centrifugation at $2795 \mathrm{~g}$ for $5 \mathrm{mn}$ and the $\mathrm{pH}$ was measured with a $\mathrm{pH}$-microelectrode (Mettler Toledo, InLab 423). The suspension aliquots were filtered through a Millipore filter $(0.45 \mu \mathrm{m})$ and stored at $277 \mathrm{~K}$ before analyses. Then the treated samples were recovered for analysis without additional rinsing and gently dried at $313 \mathrm{~K}$ in a Memmert oven until constant weight.

To estimate the reversibility of aniline sorption onto ammonium-smectite, three successive rinsings with milli-Q water were performed on ammonium-smectite samples treated with pure aniline.

\subsection{Sample characterizations}

\section{Carbon and nitrogen analyses}

Total carbon and nitrogen contents in clay samples were quantified by combustion of about $40 \mathrm{mg}$ of sample at $1573 \mathrm{~K}$ using an elemental analyzer CNS $2000 \mathrm{LECO}$. The combustion process converted any elemental carbon into $\mathrm{CO}_{2}$ which was quantified with an infrared spectroscopy cell. Nitrogen was converted into oxidized forms then reduced to $\mathrm{N}_{2}$ and quantified by conductivity measurements. Measurements were done in triplicate for each sample. The uncertainties on the concentrations of carbon $\left(\Delta \bar{C}= \pm 0.5 \mathrm{mg} \mathrm{g}^{-1}\right)$ and nitrogen $\left(\Delta \bar{N}= \pm 0.8 \mathrm{mg} \mathrm{g}^{-1}\right)$ were statistically determined on a set of measurements.

\section{Infrared spectroscopy}

Fourier Transform Infrared (FTIR) spectra were recorded using a NICOLET Magna-IR 760 Fourier transform spectrometer. To avoid $\mathrm{K}^{+}$-clay cation exchange within the sample during 
analysis (Pelletier et al., 1999) and to eliminate the contribution of water absorbed by the $\mathrm{KBr}$ pellets in the stretching O-H band, a NICOLET Nic-Plan microscope was used. The spectrometer and the microscope were purged with dry air to remove most of the atmospheric $\mathrm{H}_{2} \mathrm{O}$ and $\mathrm{CO}_{2}$. The powder sample was spread over the $\mathrm{NaCl}$ window of the microscope stage. The sample area analyzed was a $100 \mu \mathrm{m}$ diameter circle chosen under the microscope $15 \mathrm{X}$ Cassegrainian objective. The operating conditions were 128 scans and $2 \mathrm{~cm}^{-1}$ resolution with no ambient $\mathrm{CO}_{2}-\mathrm{H}_{2} \mathrm{O}$ corrections. The wave number range studied was $650-4000 \mathrm{~cm}^{-1}$ according to the spectrometer beam splitter and the microscope detector (NICOLET MCT-A). The analyses were performed in transmission mode. Experimental data were obtained by acquisition of spectra over different areas.

\section{Powder X-ray diffraction}

X-ray diffraction (XRD) patterns were recorded using a Thermo Electron ARL'XTRA diffractometer equipped with a $\mathrm{Cu}$ anode and a $\mathrm{Si}(\mathrm{Li})$ solid detector, filtering the $\mathrm{CuK} \alpha$ radiation of a standard European type X-ray tube (40 kV and $40 \mathrm{~mA})$. The vertical $\theta: \theta$ goniometer supported two Sollers slits. A VTI RH 200 Relative Humidity generator device coupled to an Anton Paar HTK 1200R chamber allowed us to work with a constant humidity rate. Experimental measurement parameters were $10 \mathrm{~s}$ counting time per $0.05^{\circ} 2 \theta$ step, from 2 to $64^{\circ} 2 \theta$. The divergence, the incident beam scatter, the diffracted beam scatter, and the receiving slits were $1.00,1.50,0.45$, and $0.30 \mathrm{~mm}$ wide, respectively. XRD analysis used between 30 and $60 \mathrm{mg}$ of random powdered sample and data collection was performed at 303 $\mathrm{K}$ and $50 \%$ relative humidity $(\mathrm{RH})$ after establishing an equilibrium period of one hour prior to each measurement.

\section{Thermo-gravimetric analyses}

The differential thermo-gravimetric analyses (DTG) were recorded with a SETARAM TGA 92 microanalyzer, from 293 to $1273 \mathrm{~K}$ with a heating rate of $5{ }^{\circ} \mathrm{C} \cdot \mathrm{mn}^{-1}$ under a flow of argon. 
Between 30 and $50 \mathrm{mg}$ of sample were used for each measurement. All samples were held at the same relative humidity before the measurements to allow comparison between the dehydration peak values.

\section{RESULTS}

Carbon and nitrogen analyses of the treated clay samples revealed three different behaviors of the studied organic molecules towards ammonium-smectite (Table 2). A first group of molecules showed a total absence of sorption onto the clay. Indeed, after interaction with acetonitrile, MTBE, dichloromethane, or benzene, the carbon content of the ammonium-clay remained constant within the experimental errors or decreased. For the second group, three organic molecules (phenol, ethanol, acetone) revealed a relatively weak sorption, as demonstrated by an increase in the quantity of carbon after interaction. Finally, the third behavior highlighted was the strong sorption of aniline onto the ammonium-smectite.

\subsection{Interaction with acetonitrile, MTBE, dichloromethane, or benzene}

The FTIR spectra of ammonium-smectite samples after interaction with acetonitrile, MTBE, dichloromethane, or benzene solution, respectively, were identical to those obtained with the starting ammonium-smectite (data not shown). These results confirmed the absence of sorption revealed by carbon and nitrogen analyses (Table 2). A small decrease in carbon concentration was even measured for some treated clays (pure acetonitrile, $0.1 \mathrm{~mol} \mathrm{~L}^{-1}$ and pure MTBE, pure dichloromethane, and pure benzene) in comparison with the sample interacted with water. The strong solvation capacity of these molecules seems to have led to the dissolution of the organic matter and/or carbonates present in the initial clay. 
Table 2: $\mathrm{pH}$ of the solution and carbon and nitrogen concentrations in treated clay samples after 7 days of interaction with water or the selected organic solutions. Initial Estimated sorbed

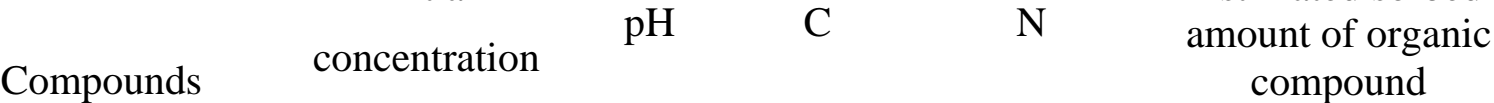
compound $\mathrm{mol} \mathrm{L}^{-1} \quad \mathrm{mg} \mathrm{g}^{-1} \quad \mathrm{mg} \mathrm{g}^{-1} \quad \mathrm{mg} \mathrm{g}^{-1}$

\begin{tabular}{|c|c|c|c|c|c|}
\hline Water & & 6.4 & $2.9 \pm 0.5$ & $7.8 \pm 0.8$ & - \\
\hline \multirow{3}{*}{ Acetonitrile } & 0.01 & 6.1 & $2.6 \pm 0.5$ & $7.0 \pm 0.8$ & - \\
\hline & 1 & 6.7 & $2.5 \pm 0.5$ & $7.4 \pm 0.8$ & - \\
\hline & pure & n.d. & $1.2 \pm 0.5$ & $8.7 \pm 0.8$ & - \\
\hline \multirow{3}{*}{$\begin{array}{c}\text { Methyl-tert- } \\
\text { butyl-ether } \\
\text { (MTBE) }\end{array}$} & 0.01 & 5.7 & $2.5 \pm 0.5$ & $6.9 \pm 0.8$ & - \\
\hline & 0.1 & 7.0 & $1.4 \pm 0.5$ & $7.1 \pm 0.8$ & - \\
\hline & pure & n.d. & $1.9 \pm 0.5$ & $6.9 \pm 0.8$ & - \\
\hline \multirow{3}{*}{ Dichloromethane } & 0.01 & 6.8 & $3.3 \pm 0.5$ & $7.2 \pm 0.8$ & - \\
\hline & 0.1 & 7.1 & $2.0 \pm 0.5$ & $7.3 \pm 0.8$ & - \\
\hline & pure & n.d. & $1.3 \pm 0.5$ & $6.7 \pm 0.8$ & - \\
\hline \multirow{2}{*}{ Benzene } & 0.01 & 6.0 & $3.0 \pm 0.5$ & $7.2 \pm 0.8$ & - \\
\hline & pure & n.d. & $1.6 \pm 0.5$ & $6.6 \pm 0.8$ & - \\
\hline \multirow[b]{2}{*}{ Phenol } & 0.01 & 6.2 & $1.8 \pm 0.5$ & $6.3 \pm 0.8$ & - \\
\hline & $\begin{array}{l}\text { saturated } \\
\text { solution }\end{array}$ & 5.3 & $15.9 \pm 0.5$ & $7.1 \pm 0.8$ & 17.0 \\
\hline \multirow{3}{*}{ Ethanol } & 0.01 & 4.5 & $8.7 \pm 0.5$ & $7.2 \pm 0.8$ & 11.2 \\
\hline & 1 & 6.6 & $2.2 \pm 0.5$ & $7.2 \pm 0.8$ & - \\
\hline & pure & n.d. & $1.1 \pm 0.5$ & $6.5 \pm 0.8$ & - \\
\hline \multirow{3}{*}{ Acetone } & 0.01 & 5.2 & $6.3 \pm 0.5$ & $7.3 \pm 0.8$ & 5.5 \\
\hline & 1 & 7.1 & $1.7 \pm 0.5$ & $7.5 \pm 0.8$ & - \\
\hline & pure & n.d. & $1.0 \pm 0.5$ & $6.5 \pm 0.8$ & - \\
\hline \multirow{3}{*}{ Aniline } & 0.01 & 7.3 & $6.2 \pm 0.5$ & $8.3 \pm 0.8$ & 4.3 \\
\hline & 0.1 & 7.2 & $17.5 \pm 0.5$ & $10.1 \pm 0.8$ & 18.9 \\
\hline & pure & n.d. & $42.8 \pm 0.5$ & $13.7 \pm 0.8$ & 51.5 \\
\hline
\end{tabular}




\subsection{Interaction with phenol, acetone, and ethanol}

At low concentration $\left(0.01 \mathrm{~mol} \mathrm{~L}^{-1}\right)$, no significant sorption of phenol was revealed by carbon analysis (Table 2) or by the comparison of FTIR spectra after interaction with water and with $0.01 \mathrm{~mol} \mathrm{~L}^{-1}$ phenol solution (Figs. 1a,b, respectively). A weak sorption was only detected at the saturation concentration in water (approximately $0.7 \mathrm{~mol} \mathrm{~L}^{-1}$ ), as shown by the measurement of a moderate quantity of carbon, which corresponds to $\mathrm{ca} 0.18 \mathrm{mmol}$ of adsorbed phenol by gram of clay. The FTIR spectrum of the ammonium-smectite after interaction with the saturated phenol solution confirmed the presence of adsorbed molecules (Figure 1c). The stretching vibrations of the aromatic cycle were observed at 1489 and 1594 $\mathrm{cm}^{-1}$ (Ovadyahu et al, 1998a). The band at $1684 \mathrm{~cm}^{-1}$ was assigned to the $v_{\mathrm{C}=\mathrm{O}}$ bond stretching of the phenol ketone form. The formation of this isomer was certainly favoured by the acidic character of the $\mathrm{NH}_{4}{ }^{+}$ion. The deformation band of water $\mathrm{H}-\mathrm{O}-\mathrm{H}$, initially at $1630 \mathrm{~cm}^{-1}$, shifted towards higher frequencies, around $1645 \mathrm{~cm}^{-1}$, whereas the deformation band of $\mathrm{NH}_{4}{ }^{+}$ $\left(1431 \mathrm{~cm}^{-1}\right)$ remained at the same wavenumber. The band around $3390 \mathrm{~cm}^{-1}$, assigned to the $v_{\mathrm{O}-\mathrm{H}}$ phenol stretching band, was difficult to identify, due to the presence of the stretching $v_{\mathrm{N}-}$ $\mathrm{H}$ bands of $\mathrm{NH}_{4}{ }^{+}$and the stretching $v_{\mathrm{O}-\mathrm{H}}$ of $\mathrm{H}_{2} \mathrm{O}$ (Fig. 1c). The sorption of ethanol and acetone was revealed at low concentration $\left(0.01 \mathrm{~mol} \mathrm{~L}^{-1}\right)$ but no sorption was observed at higher concentrations ( $1 \mathrm{~mol} \mathrm{~L}^{-1}$ and pure solution) (Table 2 ). The quantity of ethanol fixed on the clay at $0.01 \mathrm{~mol} \mathrm{~L}^{-1}$ concentration was relatively low (around $0.24 \mathrm{mmol} \mathrm{g}^{-1}$ ), and was not detected by FTIR spectroscopy (data not shown).

The quantity of adsorbed acetone deduced from carbon analysis was approximately 0.10 mmol g$~^{-1}$ of clay at $0.01 \mathrm{~mol} \mathrm{~L}^{-1}$ concentration (Table 2). FTIR spectra of the ammoniumsmectite sample after interaction with water or a $0.01 \mathrm{~mol} \mathrm{~L}^{-1}$ acetone solution are presented in Figs 2a,b, respectively. A very weak band was detected at $1720 \mathrm{~cm}^{-1}$, characteristic 


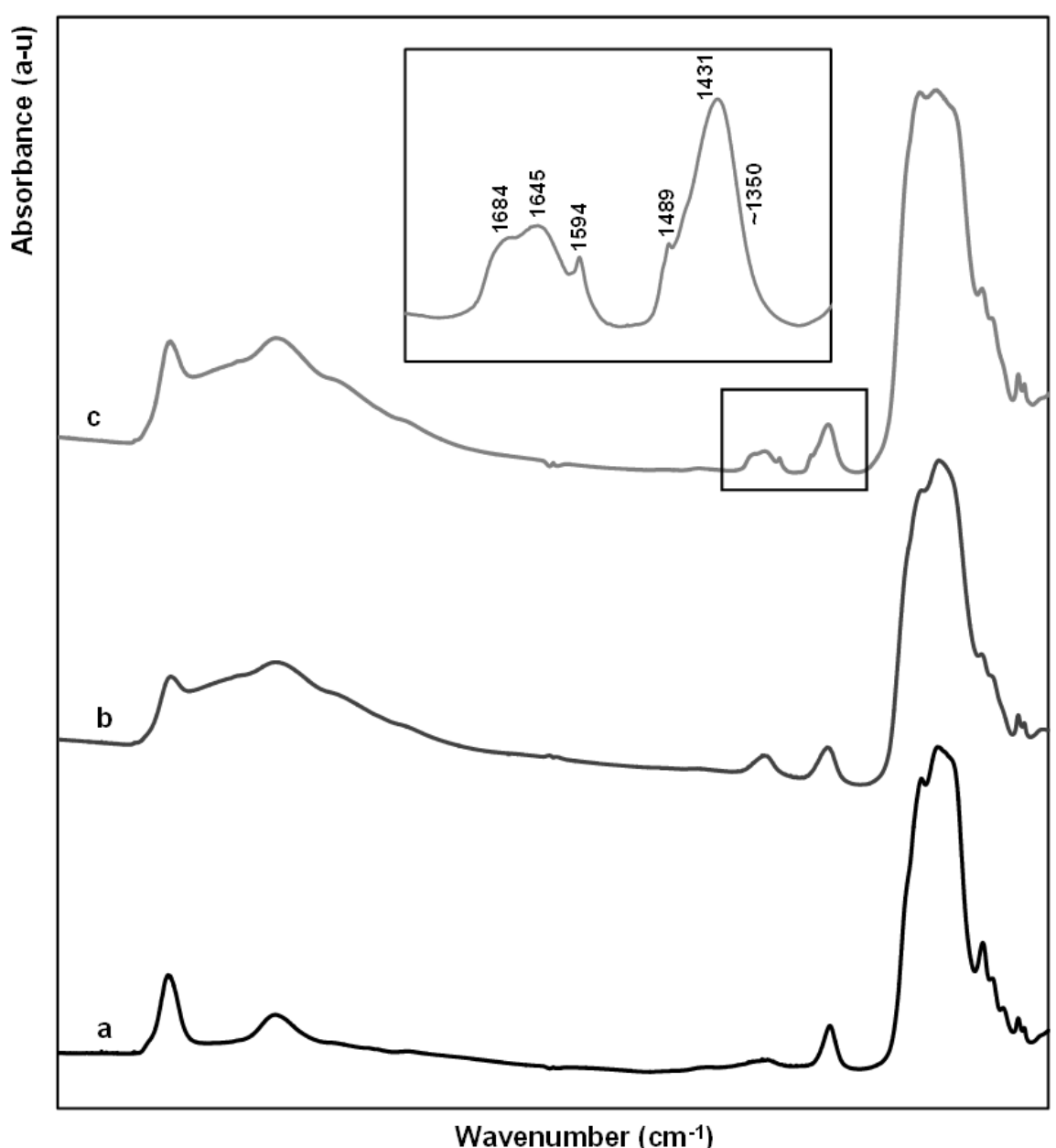

Figure 1: FTIR spectra of $\mathrm{NH}_{4}$-smectite after 7 days interaction with (a) water used as reference, (b) a $0.01 \mathrm{~mol} \mathrm{~L}^{-1}$ phenol solution, and (c) a saturated phenol solution.

of the $\mathrm{C}=\mathrm{O}$ stretching band $v_{\mathrm{C}=\mathrm{O}}$ (Doner \& Mortland, 1969) suggesting the binding of acetone on ammonium-smectite (Fig. 2b). The $\mathrm{C}-\mathrm{C}$ stretching band $\left(v_{\mathrm{C}-\mathrm{C}}\right)$ with a weak intensity was generally observed around $1200 \mathrm{~cm}^{-1}$ for ketones but was not identified in this study because of the presence of $\mathrm{Si}-\mathrm{O}$ vibrations in the same range. Similarly, the $\mathrm{NH}_{4}{ }^{+}$deformation band at $1431 \mathrm{~cm}^{-1}$ overlap the $\mathrm{CH}_{3}$ deformation bands $\left(\delta_{\mathrm{CH}}\right)$, generally expected with a weak intensity around 1380 and $1440 \mathrm{~cm}^{-1}$ (Parfitt \& Mortland, 1968).

For these three organic molecules (phenol, ethanol, and acetone) at all three concentrations, X-ray diffraction patterns were similar before and after interaction (data not shown). 


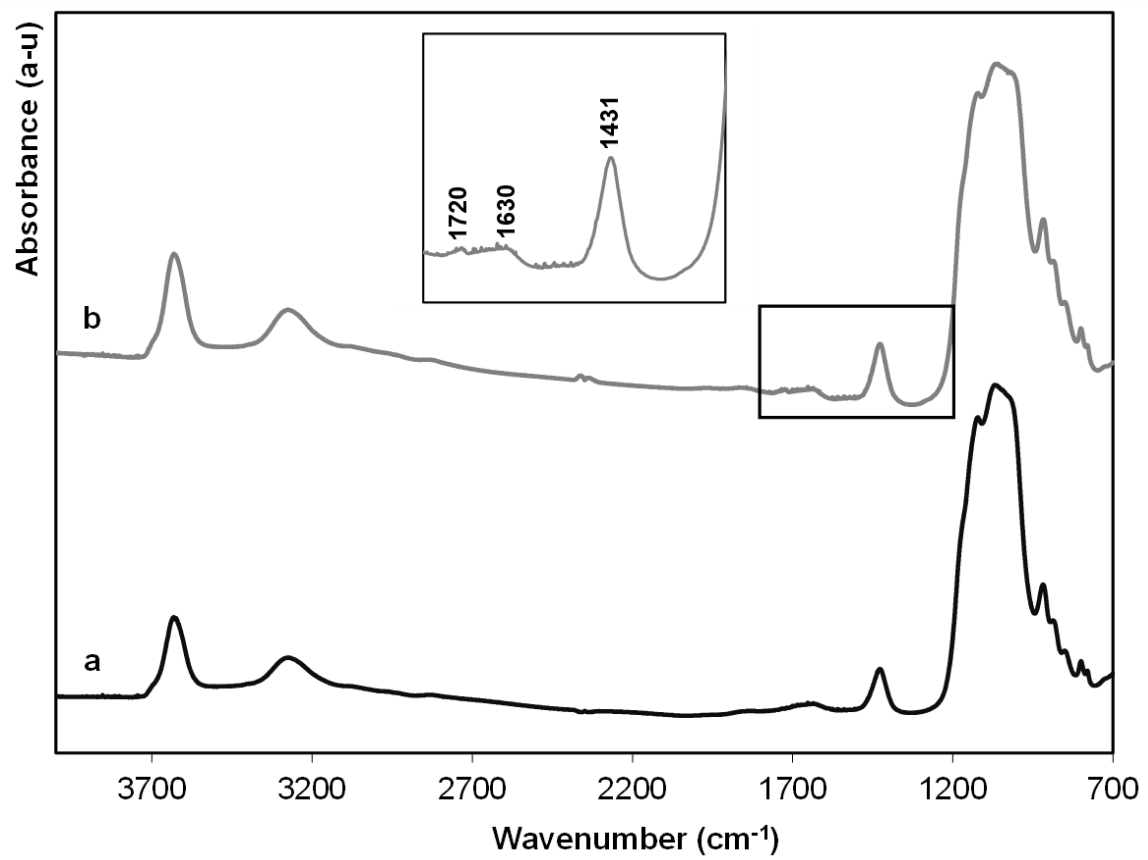

Figure 2: Infrared spectra of $\mathrm{NH}_{4}$-smectite after 7 days interaction with (a) water as reference, and (b) a $0.01 \mathrm{~mol} \mathrm{~L}^{-1}$ acetone solution.

\subsection{Interaction with aniline}

After interaction with aniline solution, $\mathrm{C}$ and $\mathrm{N}$ concentrations significantly increased in the clay, and particularly in the case of pure aniline solution (Table 2). These results clearly showed the sorption of aniline onto the ammonium-smectite. The comparison between the FTIR spectra of the reference ammonium-smectite sample and the one obtained after interaction with aniline solutions confirmed the chemical results (Fig. 3). No significant difference appeared between the interaction with water (Fig. 3a) and with $0.01 \mathrm{~mol} \mathrm{~L}^{-1}$ aniline solution (Fig. 3b), whereas new bands appeared in the case of $0.1 \mathrm{~mol} \mathrm{~L}^{-1}$ and especially 11 mol L $\mathrm{L}^{-1}$ aniline solutions (Figs. 3c and 3d). Some characteristic bands of aniline were identified from the study of Akalin \& Akyüz (1999). The FTIR spectrum of the ammoniumsmectite after interaction with pure aniline solution (Fig. 3d) showed two bands at 3386 and $3312 \mathrm{~cm}^{-1}$ characteristic of the asymmetric and symmetric stretching vibrations of 

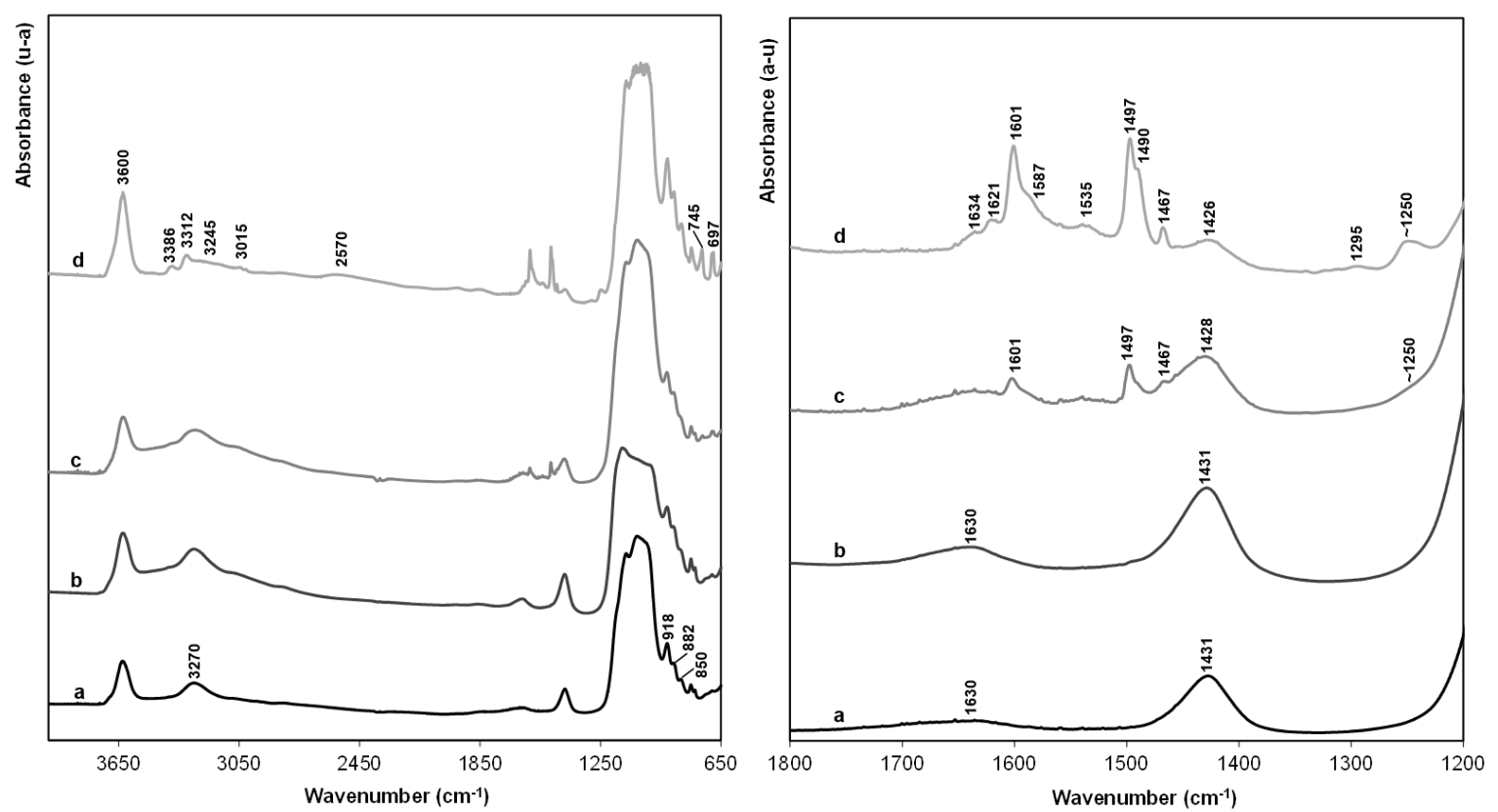

Figure 3: Infrared spectra with a specific zoom in the range $1200-1800 \mathrm{~cm}^{-1}$ of $\mathrm{NH4}$ smectite after 7 days interaction with (a) water used as reference, (b) a $0.01 \mathrm{~mol} \cdot \mathrm{L}-1$ aniline solution, (c) a $0.1 \mathrm{~mol} \cdot \mathrm{L}-1$ aniline solution and (d) a pure $\left(11 \mathrm{~mol} \cdot \mathrm{L}^{-1}\right)$ aniline solution.

the $\mathrm{N}-\mathrm{H}$ bonds of $\mathrm{NH}_{2}$. The stretching vibrations of the $\mathrm{C}-\mathrm{H}$ bonds of the aromatic cycle were also observed at $3015 \mathrm{~cm}^{-1}$ ( $\mathrm{v}_{\mathrm{C}-\mathrm{H}}$ symmetric). A large band around $2570 \mathrm{~cm}^{-1}$, characteristic of a small quantity of the aniline-anilinium ion (Yariv et al., 1968) was also identified. Additionally, the (Al, $\mathrm{Al})-\mathrm{OH}\left(918 \mathrm{~cm}^{-1}\right),(\mathrm{Al}, \mathrm{Fe})-\mathrm{OH}\left(882 \mathrm{~cm}^{-1}\right)$ and $(\mathrm{Al}, \mathrm{Mg})-$ $\mathrm{OH}\left(850 \mathrm{~cm}^{-1}\right)$ vibrations were not modified (Figs. 3a and 3d). The two new bands at $745 \mathrm{~cm}^{-1}$ and around $700 \mathrm{~cm}^{-1}$ (Fig. 3d) were assigned to the out of plane deformation bands of the C$\mathrm{H}$ bonds $\left(\gamma_{\mathrm{C}-\mathrm{H}}\right)$ and of the aromatic cycle $\left(\gamma_{\mathrm{cycle}}\right)$, respectively. Further information was obtained in the range $1200-1800 \mathrm{~cm}^{-1}$ of the FTIR spectra. The intensity of the bands that are characteristic of aniline increased along with the aniline concentration in solution. In comparison with FTIR spectra of water and $0.01 \mathrm{~mol} \mathrm{~L}^{-1}$ aniline solution (Figs. 3a and 3b), the FTIR spectrum of $0.1 \mathrm{~mol} \mathrm{~L}^{-1}$ aniline solution showed stretching bands of the $\mathrm{C}=\mathrm{C}$ bonds ( $v_{\mathrm{C}=\mathrm{C}}$ stretching) at 1601,1497 , and $1467 \mathrm{~cm}^{-1}$, and a $v_{\mathrm{C}-\mathrm{NH} 2}$ shoulder around $1250 \mathrm{~cm}^{-1}$ (Fig. $3 c$ ). The deformation vibration of $\mathrm{NH}_{2}$ ( $\delta_{\mathrm{NH}}$ scissoring) was only identified by an 


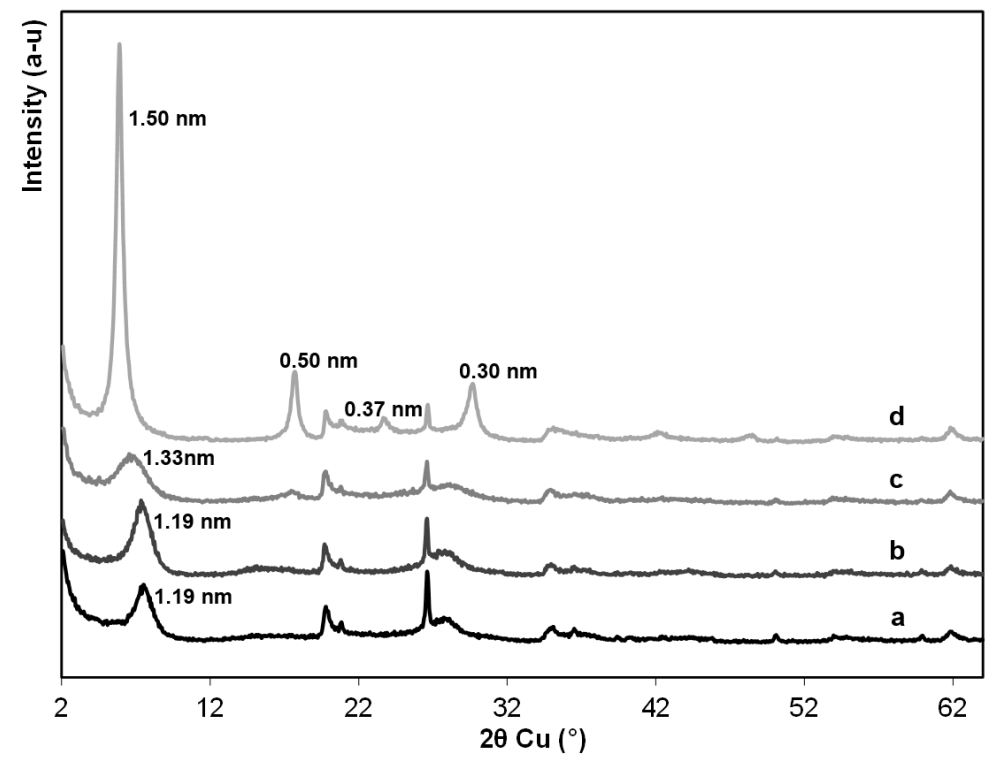

Figure 4: Differential thermo-gravimetric curves of $\mathrm{NH}_{4}$-smectite after 7 days interaction with (a) water and (b) pure aniline solution.

intense band at $1621 \mathrm{~cm}^{-1}$ in the case of the pure aniline solution (Fig. 3d). Additional bands were identified in Fig. 3d: the asymmetric and symmetric stretching bands of the $\mathrm{C}=\mathrm{C}$ bonds $\left(v_{\mathrm{C}=\mathrm{C}}\right.$ stretching) at 1601 and $1497 \mathrm{~cm}^{-1}$ (with respective shoulders at 1587 and $1490 \mathrm{~cm}^{-1}$ ), the $1535 \mathrm{~cm}^{-1}$ band attributed to the vibration of $\mathrm{NH}_{3}{ }^{+}$angular deformation $\left(\delta_{\mathrm{NH} 3+}\right)$ (Yariv \& Cross, 2002) and characteristic of the anilinium ion, a weak band around $1295 \mathrm{~cm}^{-1}$ assigned to the $\mathrm{H}-\mathrm{C}-\mathrm{H}$ deformation vibration band $({ } \mathrm{H}-\mathrm{C}-\mathrm{H})$, and the stretching band of the $\mathrm{C}-\mathrm{N}$ bonds

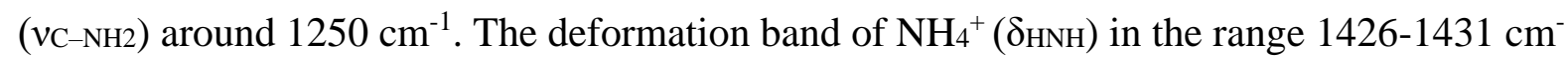
${ }^{1}$, characteristic of the ammonium interlayer cation, had a lower intensity after interaction with pure aniline compared with water (Figs. 3a,d).

The DTG curves of ammonium-smectite after interaction with water and pure aniline solution are reported in Fig. 4. The small peak at $600 \mathrm{~K}$ was attributed to the thermal decomposition of $\mathrm{NH}_{4}{ }^{+}$(Gautier et al., 2010) (Figure 4a). The treated smectite contained a lower water content, as shown by the small dehydration peak at $341 \mathrm{~K}$ (Fig. 4b). The large intense peak at $503 \mathrm{~K}$, which appeared after aniline interaction, is characteristic of the thermal decomposition of aniline complexes (Yariv, 2003). The dehydroxylation peak shifted from $878 \mathrm{~K}$ after 
interaction with water to $848 \mathrm{~K}$ after interaction with pure aniline (Fig. 4). X-ray diffraction patterns were performed on the ammonium-smectite after interaction with water and the different aniline solutions (Fig. 5). The basal spacing (d001 value) shifted from $1.19 \mathrm{~nm}$ (Fig. 5a) to $1.50 \mathrm{~nm}$ (Fig. 5d) with the increase of aniline concentration. After interaction with the $0.1 \mathrm{~mol} \mathrm{~L}^{-1}$ aniline solution, the ammonium-smectite revealed a broader 001 reflection with a higher basal spacing $(1.33 \mathrm{~nm})($ Fig. 5c). In the case of pure aniline (Fig. 5d), the 001 reflection was sharper and more intense, as well as the $003(0.50 \mathrm{~nm}), 005(0.30 \mathrm{~nm})$ and 004 $(0.37 \mathrm{~nm})$ reflections.

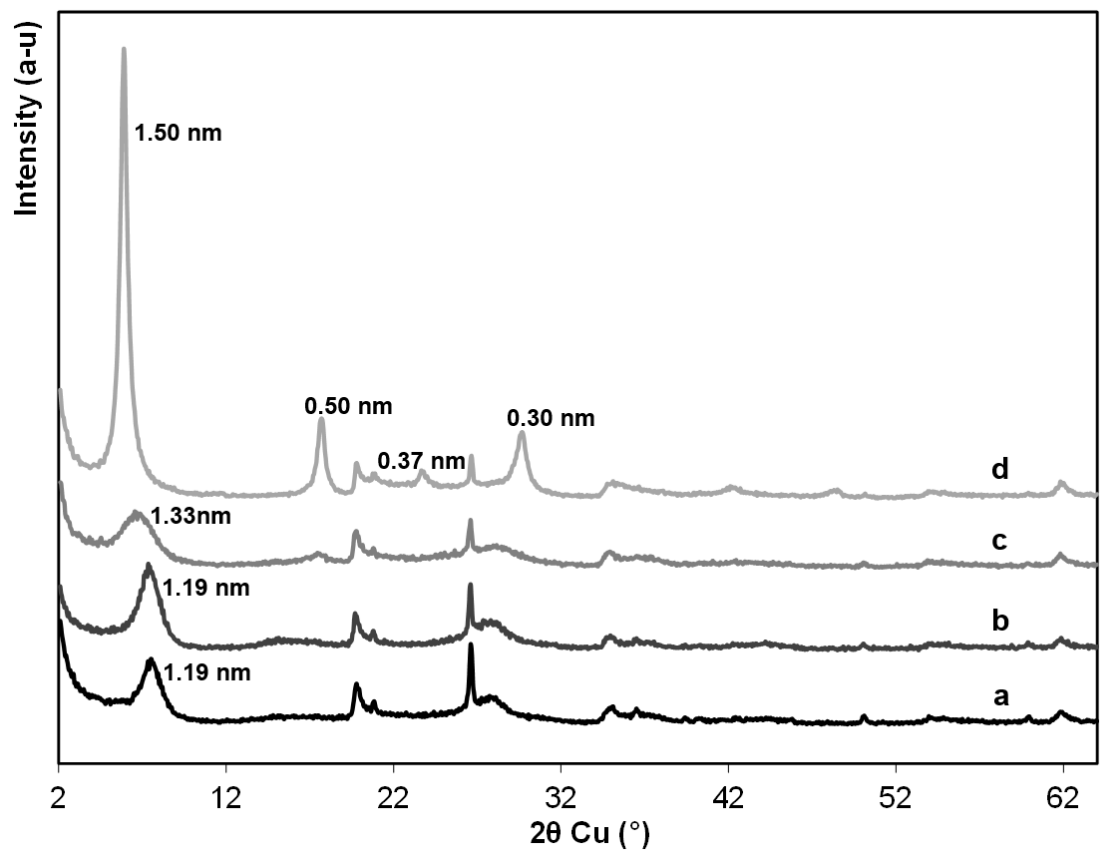

Figure 5: X-ray diffraction patterns of $\mathrm{NH}_{4}$-smectite after 7 days of interaction with (a) water used as reference, (b) a $0.01 \mathrm{~mol} \mathrm{~L}^{-1}$ aniline solution, (c) a $0.1 \mathrm{~mol} \mathrm{~L}^{-1}$ aniline solution and (d) a pure $\left(11 \mathrm{~mol} \mathrm{~L}^{-1}\right)$ aniline solution.

The infrared spectrum of the clay treated with pure aniline solution was compared to the one obtained after three successive rinsings with milli-Q water (Fig. 6). After rinsing (Fig. 6b) a general decrease in the intensity of the bands characteristic of binding with aniline 


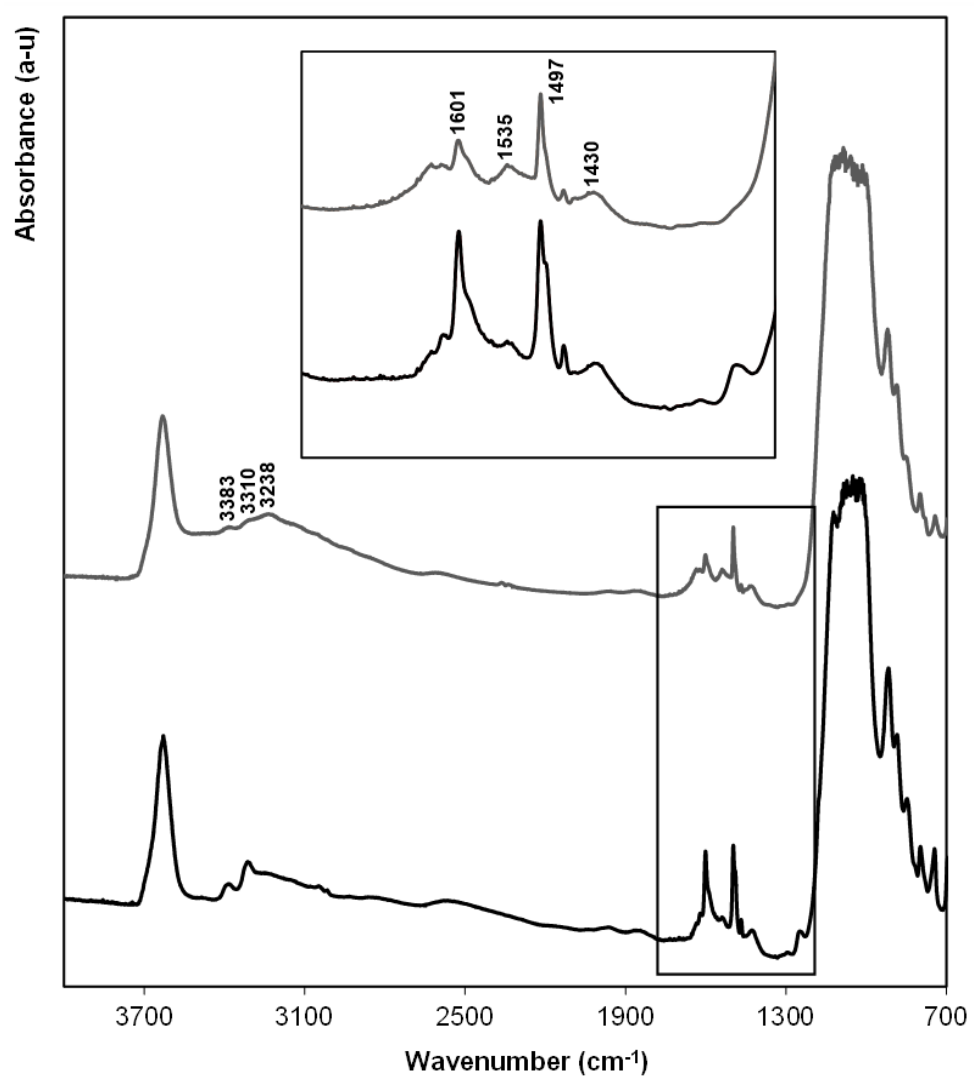

Figure 6: Infrared spectra of ammonium-smectite after 7 days interaction with (a) pure aniline and (b) pure aniline then rinsed with milli-Q water.

molecules was observed $\left(3383,3310,1601,1497\right.$ and $\left.1469 \mathrm{~cm}^{-1}\right)$. The X-ray diffraction pattern of the clay treated with pure aniline solution was compared to the one obtained after three successive rinsings with milli-Q water (Fig. 7). The basal spacing of the treated sample shifted from 1.50 to $1.35 \mathrm{~nm}$ after rinsing, the 001 reflection became wider and the 003 reflection disappeared. 


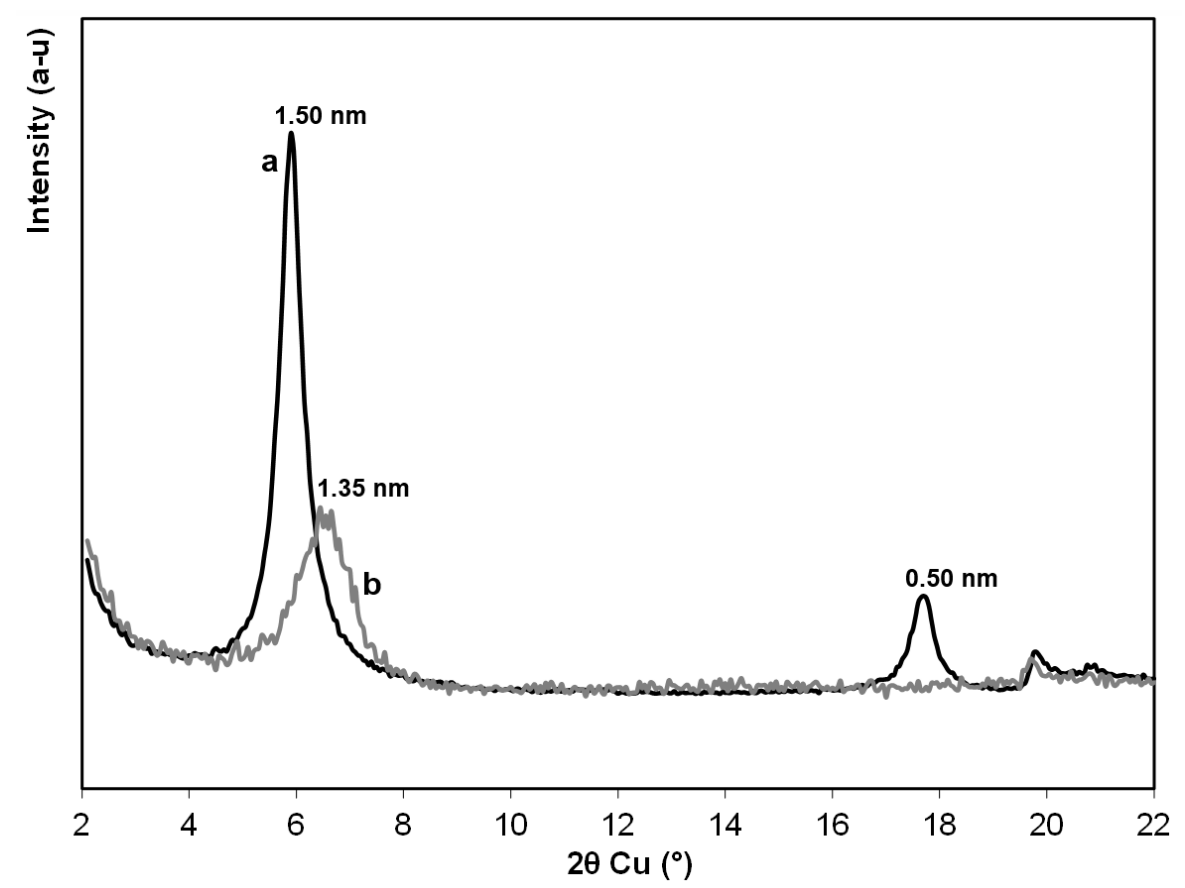

Figure 7: X-ray diffraction patterns of ammonium-smectite after 7 days interaction with (a) pure aniline and (b) pure aniline then rinsed with milli-Q water.

\section{DISCUSSION}

\subsection{Non retained molecules}

The absence of sorption onto ammonium smectite observed with acetonitrile, MTBE, dichloromethane, and benzene is in good agreement with previous studies performed on smectites with other interlayer cations. Hoffmann \& Brindley (1960) studied the adsorption of non-ionic aliphatic compounds in solution onto a Ca-montmorillonite, in particular nitrile, ether, and alcohols. They showed that the length of the chain had a great influence on the adsorption of these molecules, and that a minimum chain length of 5 or $6 \mathrm{CH}_{2}$ units was necessary to obtain sorption. Acetonitrile and MTBE are constituted of short chains, which prevented them from being sorbed in the ammonium-smectite. Furthermore, the weak and easily reversible sorption of acetonitrile on $\mathrm{K}-, \mathrm{Na}-\mathrm{Ca}-$, and $\mathrm{Mg}$-exchanged montmorillonites was already demonstrated by FTIR spectroscopy (Zhang et al., 1990b, 1990c). Similarly, Greenwood et al. (2007) highlighted the very weak sorption of MTBE on clays. Among the 
compounds studied, dichloromethane has the highest vapor pressure and a very fast evaporation in ambient conditions, which easily explains the absence of binding in aqueous solution. The absence of benzene adsorption onto ammonium smectite is in accordance with the results of Jaynes \& Vance (1999) onto Na-, K-, Ca- and Mg-montmorillonites. The dipole moment of benzene is zero, due to its symmetry, which considerably limits the dipole-dipole interactions with the hydrophilic surface of the smectites and leads to a very low adsorption.

\subsection{Weakly retained molecules}

\section{Phenol}

Phenol sorption onto clays has been extensively described in the literature, both on clays with inorganic interlayer cations (Isaacson \& Sawhney, 1983; Ovadyahu et al., 1998a, 1998b; Viraraghavan \& de Maria Alfaro, 1998; Yapar \& Yilmaz, 2005; Richards \& Bouazza, 2007; Djebbar et al., 2012; Janík et al., 2013), and with organoclays (Zhang \& Sparks, 1993; Dentel et al., 1995; Koh \& Dixon, 2001; Yilmaz \& Yapar, 2004; Richards \& Bouazza, 2007; Alkaram et al., 2009; Díaz-Nava et al., 2012), but never on ammonium-exchanged clays. Phenol adsorption is known to be $\mathrm{pH}$-dependent (Viraraghavan \& de Maria Alfaro, 1998, Yilmaz \& Yapar, 2004, Yapar \& Yilmaz, 2005) also showed that the adsorption of phenol is dependent on the $\mathrm{pH}$. In our batch experiments, the $\mathrm{pH}$ of the solution after interaction with phenol varied between 5.3 and 6.2 (Table 2), which imposed the neutral form of the phenol molecule $(\mathrm{pKa}=9.95)$, preventing the formation of electrostatic bonds. The stretching vibrations of the aromatic cycle observed at 1489 and $1594 \mathrm{~cm}^{-1}$ can be attributed to hydrogen bonds between the neutral phenol molecules and the water molecules in the hydration shell of the interlayer cations (Ovadyahu et al., 1998a, 1998b). Two binding configurations involving a hydrogen bond between the phenol group and water molecules were suggested (Fig. 8). 


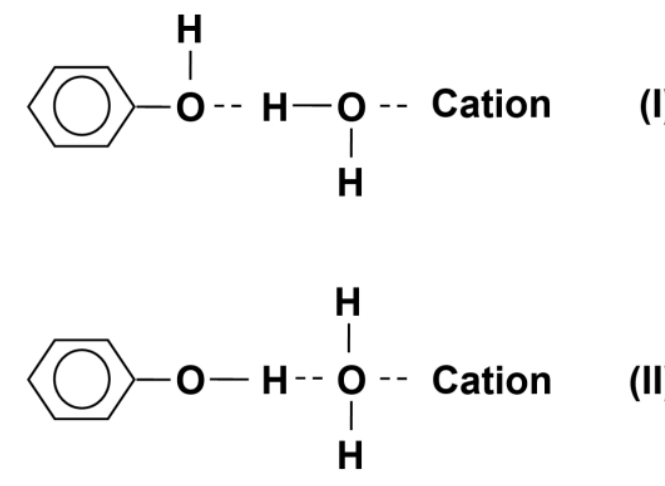

(I)

\section{Figure 8: Possible configurations of binding involving a hydrogen bond between phenol group and water molecule.}

Configuration (I) requires the breaking of the $\mathrm{H}$-bond between the hydration water molecules and the oxygen atoms of the clay layers. In configuration (II), the hydrogen of the phenol group binds with the oxygen atom of the water molecule. Because of the weak polarizing power $(\mathrm{Z} / \mathrm{r}$ where $\mathrm{Z}$ is the charge and $\mathrm{r}$ the ionic radius of the cation) of monovalent interlayer cations (1.02 for $\mathrm{Na}^{+}, 0.75$ for $\mathrm{K}^{+}$and $\cong 0.69$ for $\mathrm{NH}_{4}^{+}$), the $\mathrm{H}$-bond between hydration water and clay layers will be easy to break, and configuration (I) will be generally the most common case (Fenn \& Mortland, 1972). The similar XRD patterns obtained after interaction with water and with phenol solution indicated that the aromatic groups of phenols were placed parallel to the layers as already observed in sodium and potassium montmorillonite by Saltzman \& Yariv (1975). The adsorption of phenol molecules onto the surface of natural clay, through hydrogen bonds between $\mathrm{OH}$ group of the phenol and the silanol groups of the clay surface could also be possible. Moreover Djebbar et al. (2012) measured enthalpy values and suggested a physisorption at the surface conducted with Van der Waals forces. The sorption of phenol remained very weak and easily reversible, because it was totally desorbed after a few days at $313 \mathrm{~K}$.

\section{Ethanol and acetone}


Dissociation forms of ethanol and acetone are negligible for the $\mathrm{pH}$ values of the solution (Table 1) because of their high pKa values (16 and 19.3 for ethanol and acetone respectively, Table 2). Configuration (I) shows a hydrogen bond between the nitrogen from aniline and the hydrogen from water molecule. Configuration (II) shows a hydrogen bond between a hydrogen from aniline and the oxygen from water molecule. There are several possible explanations why small quantities of acetone and ethanol fixed on the $\mathrm{NH}_{4}{ }^{+}$-smectite at low concentration $\left(0.01 \mathrm{~mol} \mathrm{~L}^{-1}\right)$. German \& Harding (1969) showed that the adsorption of aliphatic alcohols onto a kaolinite or a montmorillonite saturated with calcium and sodium cations depended on the length of the carbonaceous chain and on the nature of the cation. Hoffmann \& Brindley (1960) observed that a minimum chain length of five carbon units (methyl and/or methylene groups) was necessary to obtain a significant adsorption from the aqueous phase. The sorption capacity of ethanol with only two carbon units is therefore likely to be very low. Zhang et al. (1990a) demonstrated that ethanol was not fixed by a chemical bond to the layer surface but with Van der Waals forces which are much weaker. As in the case of ethanol, the adsorption of acetone molecules was partly due to Van der Waals interactions, as shown by Bissada et al.(1967). They studied the adsorption of ethanol and acetone in liquid state on dehydrated montmorillonites. The authors demonstrated the possibility of a cation-dipole interaction and showed an increase in adsorption depending on the nature of the cation in the order $\mathrm{K}^{+}<\mathrm{Na}^{+}<\mathrm{Ba}^{2+}<\mathrm{Ca}^{2+}$. Because the ionic radius of ammonium is larger than that of potassium, the interaction energy will be weaker and adsorption on ammonium-clay with cation-dipole interaction should be very weak. Moreover Van der Waals forces can also occurred with layer surface.

A hypothesis to explain the presence of ethanol and acetone fixed at weak concentration and their absence at stronger ones is the difference between the boiling point or vapour pressure between water and organic compounds. Ethanol and acetone, with vapour pressures of 5.9 and 
$23.3 \mathrm{kPa}$ at $293 \mathrm{~K}$, respectively, are more volatile than water vapour pressure of $2.34 \mathrm{kPa}$ at 293 K. Regarding the binary diagrams water-ethanol and water-acetone it is well established that the energy needed to reach the boiling point of a mixture rich in water is higher that one with higher organic compounds content. In these conditions the drying at $313 \mathrm{~K}$ might explain the difference in residual fixed molecules and why more energy was needed in the case of low concentration.

\subsection{Strongly retained molecule: aniline}

With a pKa value of 4.6 for the anilinium/aniline couple, anilinium exists in small proportions in aqueous solution ( $\mathrm{pH}=7.3$; Table 2 ) and cationic exchange with $\mathrm{NH}_{4}{ }^{+}$must be considered. The FTIR spectrum for pure aniline clearly highlighted the presence of a small quantity of the anilinium and aniline-anilinium ions (Yariv et al., 1968) and reported in Fig. 9. These authors also showed that the formation of anilinium may occur directly in the interlayer space by the reaction: $\mathrm{C}_{6} \mathrm{H}_{5} \mathrm{NH}_{2}+\mathrm{NH}_{4}^{+} \Leftrightarrow \mathrm{C}_{6} \mathrm{H}_{5} \mathrm{NH}_{3}{ }^{+}+\mathrm{NH}_{3}$.

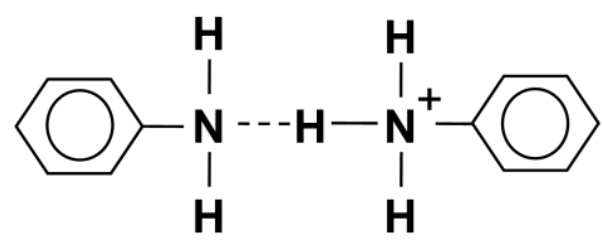

Figure 9. Structure of binding for aniline-anilinium ion.

The intercalation of aniline in the interlayer was clearly shown by FTIR analyses. The shift of the dehydroxylation peak observed in the DTG study indicated the position of aniline near the $\mathrm{OH}$ groups and confirmed this result. The similar basal spacing after interaction with water and with $0.01 \mathrm{~mol} \mathrm{~L}^{-1}$ aniline solution $\left(\mathrm{d}_{001}=1.19 \mathrm{~nm}\right.$, Figs. $5 \mathrm{a}$ and $\left.5 \mathrm{~b}\right)$ indicated that the 
aniline molecules were placed parallel to the layers. This arrangement was already observed by Saltzman \& Yariv (1975) in the case of a plane aromatic molecule (phenol) with a d001 value of $1.18 \mathrm{~nm}$. After interaction with the $0.1 \mathrm{~mol} \mathrm{~L}^{-1}$ aniline solution, the broader 001 reflection with a higher basal spacing $\left(\mathrm{d}_{001}=1.33 \mathrm{~nm}\right.$, Fig. 6) is characteristic of a disorder in the inter-layered clay stack. Some molecules occupied intermediate positions between parallel and perpendicular orientation to the sheets (Theng, 1974). In the case of pure aniline, the better organization of the smectite observed by XRD and the $\mathrm{d}_{001}=1.5 \mathrm{~nm}$ suggests that the aniline molecules were intercalated perpendicular to the clay layers (Farmer \& Mortland, 1966). Yariv et al. (1969) studied the intercalation of aniline into montmorillonite exchanged with $\mathrm{Al}, \mathrm{Mg}, \mathrm{H}, \mathrm{Na}$, or $\mathrm{K}$ cations. They showed that aniline formed hydrogen bonds with the interlayer water molecules connected to interlayer cations and proposed two binding configurations (Fig. 10). In the case of $\mathrm{NH}_{4}$ exchanged montmorillonite, which has a low polarizing power $(\mathrm{Z} / \mathrm{r} \cong 0.69$ where $\mathrm{Z}$ is the cation charge and $\mathrm{r}$ its radius $)$, the $\mathrm{H}$-bond between hydration water and clay layers will be easy to break. So configuration I will be dominant, where both hydrogen atoms of aniline are free in comparison with configuration II where a hydrogen of the $\mathrm{NH}_{2}$ group binds with the oxygen atom of the water molecule. The symmetric and asymmetric $\mathrm{NH}_{2}$ stretching bands, respectively at $3312 \mathrm{~cm}^{-1}$ and $3386 \mathrm{~cm}^{-1}$ $\left(v_{\mathrm{N}-\mathrm{H}}\right.$, Fig. 3d) confirmed this predominance (Yariv et al., 1969). Another configuration in which the aniline molecule was directly bound to $\mathrm{NH}_{4}{ }^{+}$was proposed by Yariv \& Cross (2002). This configuration only concerned very weakly hydrated environments and high aniline concentrations. 
<smiles>OCCOCCO</smiles><smiles>OCCOCCNc1ccccc1</smiles>

(I)

\section{Figure 10: Possible configurations of binding involving a hydrogen bond between aniline and interfoliar water molecule.}

The fixation of aniline molecules on the ammonium interlayer cations was strengthened by the shift of the main stretching vibration bands ( $v_{\mathrm{N}-\mathrm{H}}$ of a $\mathrm{NH}_{4}{ }^{+}$group) from $3270 \mathrm{~cm}^{-1}$ in the starting sample (Fig. 3a) to around $3245 \mathrm{~cm}^{-1}$ after interaction with pure aniline (Fig. 3d), and corresponding to a decrease in the $\mathrm{N}-\mathrm{H}$ bond strength of the interlayer cation. The shift of some bands characteristic of the FTIR spectrum of pure aniline to lower wavenumbers after interaction with the ammonium-smectite also confirmed the sorption of aniline on ammonium-smectite: the asymmetric and symmetric stretching bands $\left(v_{\mathrm{N}-\mathrm{H}}\right.$ of $\left.\mathrm{NH}_{2}\right)$ shifted from 3500 and $3418 \mathrm{~cm}^{-1}$ in pure liquid aniline (Akalin \& Akyüz, 1999) to 3386 and $3312 \mathrm{~cm}^{-}$ ${ }^{1}$ after interaction with ammonium-smectite (Fig. 3d), and the stretching vibration band of the C-N bond ( $\left.v_{\mathrm{C}-\mathrm{NH} 2}\right)$ decreased from $1279 \mathrm{~cm}^{-1}$ in pure liquid aniline (Akalin \& Akyüz, 1999) to approximately $1250 \mathrm{~cm}^{-1}$ (Fig. 3d). Note that a small proportion of aniline may also adsorb onto the surfaces and the edges of the clay particles (Yan \& Bailey, 2001; Vasudevan et al., 2013). The intercalation of aniline on ammonium-smectite was accompanied by a decrease in the hydrophilic character of the material as shown by the strong decrease in the intensity of the dehydration peak in DTG analyses (Fig. 4b). The decrease in the intensity of the bands characteristic of the binding between aniline and ammonium-smectite after rinsing the ammonium-smectite treated with aniline solution (Fig. 6) indicated a partial desorption of 
aniline. The basal spacing shifted from 1.50 to $1.35 \mathrm{~nm}$ after rinsing the ammonium-smectite treated with aniline solution (Fig. 7) confirmed the partial desorption of aniline.

\section{CONCLUSION}

This study focused on eight short chain VOCs contained in landfill leachate interacting with ammonium-smectite. The sorption success for these organic compounds on ammoniumsmectite mainly depends on the magnitude of the interactional processes that ensure both cohesion and stability in the resulting materials. The absence of sorption observed with acetonitrile, methyl tert-butyl ether, dichloromethane, and benzene, is in agreement with previous studies. Phenol, ethanol, and acetone were very weakly sorbed. Van der Waals interactions with clay layers and cation-dipole interactions allowed the sorption of ethanol, acetone and phenol. For phenol sorption hydrogen bonds between hydroxyl groups and interlayer water molecules, whereas The higher volatility of both ethanol and acetone in comparison with water led to a decrease in the amount of molecules fixed with the increase in the solvent concentration. In contrast, aniline was strongly sorbed on ammonium-smectite, and only partially desorbed after rinsing. The proposed model of sorption was a binding of aniline on the $\mathrm{NH}_{4}{ }^{+}$cations, with the formation of $\mathrm{H}$-bonds through interlayer water molecules. Moreover, aniline can be retained by other processes: (i) by cationic exchange of $\mathrm{NH}_{4}{ }^{+}$by anilinium ions in small proportions; (ii) by anilinium formation following the reaction $\mathrm{C}_{6} \mathrm{H}_{5} \mathrm{NH}_{2}+\mathrm{NH}_{4}{ }^{+} \Leftrightarrow \mathrm{C}_{6} \mathrm{H}_{5} \mathrm{NH}_{3}{ }^{+}+\mathrm{NH}_{3}$; and (iii) by the formation of the anilineanilinium ion in the clay interlayer. The sorption models for phenol, ethanol, acetone, and aniline in an ammonium smectite were identical to those proposed in the literature for smectites containing $\mathrm{Ca}^{2+}$ or $\mathrm{Na}^{+}$as interlayer cations. 
The interaction processes involved in the sorption of these eight VOCs on ammonium smectite can be transposed to clay barriers. Only an easily reversible physisorption was possible for acetonitrile, methyl tert-butyl ether, dichloromethane, and benzene. These four molecules contained in leachates will not be retained by the engineered clay barriers, and therefore present a potential hazard for the pollution of groundwaters. Phenol, ethanol, and acetone will not be strongly retained by the clayey barrier and may also migrate towards groundwaters, as previously shown by Zhang et al. (1990a) for phenol and ethanol in water/soil systems. The clay barrier proved to be effective for aniline sorption. However, this sorption decreased the hydrophilic character of the ammonium-smectite, which may reduce its swelling capacity, and therefore may increase the permeability of the clay barrier.

\section{Acknowledgments}

The authors gratefully thank Jean-Michel Bény for his assistance with FTIR experiments, and Marielle Hatton for help in using the LECO analyzer.

\section{References}

Akalin E. \& Akyüz S. (1999) Force field and IR intensity calculations of aniline and transition metal(II) aniline complexes. Journal of Molecular Structure, 482, 175-181. DOI: 10.1016/S0022-2860(98)00780-7

Alkaram U.F., Mukhlis A.A., Al-Dujaili A.H. (2009) The removal of phenol from aqueous solutions by adsorption using surfactant-modified bentonite and kaolinite. Journal of Hazardous Materials, 169, 324-332. doi: 10.1016/j.jhazmat.2009.03.153

Amarasinghe P.M., Katti K.S. \& Katti D.R. (2009) Nature of organic fluid-montmorillonite interactions: An FTIR spectroscopic study . Journal of Colloid and Interface Science, 337, 97-105. DOI:10.1016/j.jcis.2009.05.011

Bishop J.L., Banina A., Mancinelli R.L. \& Klovstad M.R. (2002) Detection of soluble and fixed $\mathrm{NH}_{4}{ }^{+}$in clay minerals by DTA and IR reflectance spectroscopy: a potential tool for planetary surface exploration. Planetary and Space Science, 50, 11-19. DOI: 10.1016/S00320633(01)00077-0 
Bissada K.K., Johns W.D. \& Cheng F.S. (1967) Cation-dipole interactions in clay organic complexes. Clay Minerals, 7, 155-166.

Bolan N.N., Wong L. \& Adriano D.C. (2004) Nutrient removal from farm effluents. Bioresource Technology, 94, 251-260. DOI:10.1016/j.biortech.2004.01.012

Bouwman L., Goldewijk K.K., van Der Hoek K.W., Beusen A.H., van Vuuren D.P., Willems J., Rufino M.C. \& Stehfest E. (2013) Exploring global changes in nitrogen and phosphorus cycles in agriculture induced by livestock production over the 1900-2050 period. Proceedings of the National Academy of Science of the United States of America, 110, 20882-20887. DOI: $10.1073 /$ pnas. 1012878108

Bright M.I, Thornton S.F., Lerner J.H. \& Tellam J.H. (2010) Attenuation of landfill leachate by clay liner materials in laboratory columns, 1 . Experimental procedures and behavior of organic contaminants. Waste Management \& Research, 18, 198-214.

DOI: $10.1177 / 0734242 X 0001800302$

Çelik M.S., Özdemir B., Turan M., Koyuncu I., Atesok G. \& Sarikaya H.Z. (2001) Removal of ammonia by natural clay minerals using fixed and fluidised bed column reactors. Book Series Water Science and Technology: Water Supply, 1, 81-88.

Chipera S.J. \& Bish D.L. (2001) Baseline studies of the Clay Minerals Society Source Clays: powder X-ray diffraction analyses. Clays and Clay Minerals, 49, 398-409.

DOI:10.1346/CCMN.2001.0490507

Christensen T.H., Kjeldsen P., Bjerg P.L., Jensen D.L., Christensen J. B., Baun A., Albrechtsen H.J. \& Heron G. (2001) Biogeochemistry of landfill leachate plumes. Applied Geochemistry, 16, 659-718. DOI:10.1016/S0883-2927(00)00082-2

Clausen P. (2013) Kinetics of desorption of water, ethanol, ethyl acetate, and toluene from a montmorillonite. Clays and Clay Minerals, 61, 361-374. DOI:10.1346/CCMN.2013.0610414

Dentel S.K., Bottero J.Y., Khatib K., Demougeot H., Duguet J.P. \& Anselme C. (1995) Sorption of tannic acid, phenol and 2,4,5-trichlorophenol on organoclays. Water Research, 29, 1273-1280. DOI:10.1016/0043-1354(94)00277-E

Díaz-Nava M. C., Olguín M. T., Solache-Ríos M. (2012) Adsorption of phenol onto surfactants modified bentonite. Journal of Inclusion Phenomena and Macrocyclic Chemistry, 74, 67-75.

Djebbar M., Djafri F., Bouchekara M., Djafri A. (2012) Adsorption of phenol on natural clay. Applied Water Science, 2, 77-86.

Doner H.E. \& Mortland M.M. (1969) Intermolecular interaction in montmorillonites: NH-CO sytems. Clays and Clay Minerals, 17, 265-270.

Edil T.B. (2003) A review of aqueous-phase VOC transport in modern landfill liners. Waste Management, 23, 561-571. DOI:10.1016/S0956-053X(03)00101-6 
EPA (2015) Advancing Sustainable Materials Management: Facts and Figures 2013. Assessing Trends in Materials Generation, Recycling and Disposal in the United States. 22p.

Eturki S., Ayari F., Jedidi N. \& Ben Dhia H. (2012) Use of clay mineral to reduce ammonium from wastewater. Effect of various parameters. Surface Engineering and Applied Electrochemistry, 48, 276-283. DOI: 10.3103/S1068375512030064

Eurostat. Environmental Data Centre on Waste. (2015) Municipal waste statistics.

Farmer V.C. \& Mortland M.M. (1966) An infrared study of the co-ordination of pyridine and water to exchangeable cations in montmorillonite and saponite. Journal of the Chemical Society A - Inorganic Physical Theoretical, 3, 344-351. DOI:10.1039/j19660000344

Fenn D.B. \& Mortland M.M. (1972) Interlamellar metal complexes on layer silicates. II. Phenol complexes in smectites. Pp. 591-603 in: Proceedings of the International Clay Conference, Madrid, Spain.

Gautier M., Muller F., Bény J.M., Le Forestier L., Albéric P. \& Baillif P. (2009) Interactions of ammonium smectite with low-molecular-weight carboxylic acids. Clay Minerals, 44, 207 219. DOI:10.1180/claymin.2009.044.2.207

Gautier M., Muller F., Le Forestier L., Bény J.M. \& Guégan R. (2010) NH4-smectite: Characterization, hydration properties and hydro mechanical behaviour. Applied Clay Science, 49, 247-254. DOI:10.1016/j.clay.2010.05.013

German W.L. \& Harding D.A. (1969) The adsorption of aliphatic alcohols by montmorillonite and kaolinite. Clay Minerals, 8, 213-227.

Ghayaza M., Le Forestier L., Muller F., Tournassat C. \& Bény J.M. (2011) Pb(II) and Zn(II) adsorption onto $\mathrm{Na}$ - and $\mathrm{Ca}$-montmorillonites in acetic acid/acetate medium: Experimental approach and geochemical modeling. Journal of Colloid and Interface Science, 361, 238-246. DOI: $10.1016 /$ j.jcis.2011.05.028

Gieskes J.M. \& Mahn C. (2007) Halide systematics in interstitial waters of ocean drilling sediment cores. Applied Geochemistry, 22, 515-533. DOI:10.1016/j.apgeochem.2006.12.003

Greenwood M.H., Sims R.C., McLean J.E., Doucette W.J. \& Kuhn J. (2007) Sorption of methyl tert-butyl ether (MTBE) and tert-butyl alcohol (TBA) to hyporheic zone soils. Soil and Sediment Contamination, 16, 423-431. DOI:10.1080/15320380701404672

Hoffmann R.W. \& Brindley G.W. (1960) Clay-organic studies. 2. Adsorption of non-ionic aliphatic molecules from aqueous solutions on montmorillonite. Geochimica and Cosmochimica Acta, 20, 15-29. DOI:10.1016/0016-7037(60)90135-6

Isaacson P. J. \& Sawhney B. L. (1983) Sorption and transformation of phenols on clay surfaces: effect of exchangeable cations. Clay Minerals, 18, 253-265.

Janík R., Jóna E., Pavlík V., Lizák P. \& Mojumdar S.C. (2013) Interactions of 2,5- and 3,5dimethylphenols with co-exchanged montmorillonite : Thermal, IR-spectral and X-ray 
studies. Journal of Thermal Analysis and Calorimetry, 112, 1083-1087.

DOI:10.1007/s10973-013-3012-8

Jaynes W.F. \& Vance G.F. (1999) Sorption of benzene, toluene, ethylbenzene, and xylene (BTEX) compounds by hectorite clays exchanged with aromatic organic cations. Clays and Clay Minerals, 47, 358-365. DOI:10.1346/CCMN.1999.0470312

Jensen D.L. \& Christensen T.H. (1999) Colloidal and dissolved metals in leachates from four Danish landfills. Water Research, 33, 2139-2147. DOI:10.1016/S0043-1354(98)00414-X

Kim B., Gautier M., Molle P., Michel P. \& Gourdon R. (2015) Influence of the water saturation level on phosphorus retention and treatment performances of vertical flow constructed wetland combined with trickling filter and $\mathrm{FeCl}_{3}$ injection. Ecological Engineering, 80, 53-61. DOI:10.1016/j.ecoleng.2014.09.097

Kim B., Gautier M., Prost-Boucle S., Molle P., Michel P. \& Gourdon R. (2014) Performance evaluation of partially saturated vertical-flow constructed wetland with trickling filter and chemical precipitation for domestic and winery wastewaters treatment. Ecological Engineering, 71, 41-47. DOI:10.1016/j.ecoleng.2014.07.045

Kjeldsen P. \& Christophersen M. (1999) Composition of leachate from old landfills in Denmark. Pp. 105-112 in: Proceedings of the Seventh International Waste Management and Landfill Symposium, Sardinia'99 (CISA Publisher). Environmental Sanitary Engineering Centre, Cagliari, Italy.

Kjeldsen P., Barlaz M.A., Rooker A.P., Baun A., Ledin A. \& Christensen T.H. (2002) Present and long-term composition of MSW landfill leachate: A review. Critical Reviews in Environmental Science and Technology, 32, 297-336. DOI:10.1080/10643380290813462

Koh S.M. \& Dixon J.B. (2001) Preparation and application of organo-minerals as sorbents of phenol, benzene and toluene. Applied Clay Science, 18, 111-122. DOI:10.1016/S01691317(00)00040-5

Kowalska M, Güler H. \& Cocke D. L. (1994) Interactions of clay minerals with organic pollutants. The Science of the Total Environment, 141, 223-240.

Kruempelbeck I. \& Ehrig H.J. (1999) Long-term behaviour of municipal solid waste landfills in Germany. Pp. 27-36 in: Proceedings of the Seventh International Waste Management and Landfill Symposium, Sardinia'99 (CISA Publisher). Environmental Sanitary Engineering Centre, Cagliari, Italy.

Lake C.B. \& Rowe R.K. (2004) Volatile organic compound diffusion and sorption coefficients for a needle-punched GCL. Geosynthetics International, 11, 257 -272. DOI: 10.1680/gein.2004.11.4.257

Lake C.B. \& Rowe R.K. (2005) A comparative assessment of volatile organic compound (VOC) sorption to various types of potential GCL bentonites. Geotextiles and Geomembranes, 23, 323-347. DOI:10.1016/j.geotexmem.2005.01.001 
Lo I.M.C. (1996) Characteristics and treatment of leachates from domestic landfills. Environment International, 22, 433-442. DOI:10.1016/0160-4120(96)00031-1

Mingram B. \& Bräuer K. (2001) Ammonium concentration and nitrogen isotope composition in metasedimentary rocks from different tectonometamorphic units of the European Variscan belt. Geochimica and Cosmochimica Acta, 65, 273-287. DOI: 10.1016/S00167037(00)00517-2

Mohammed-Azizi F., Dib S. \& Boufatit M. (2011) Algerian montmorillonite clay as adsorbent for the removal of aniline from the aqueous system. Desalination and Water Treatment, 30, 74-79. DOI:10.5004/dwt.2011.1447

Moore, D.E. and Reynolds, R.C., Jr. (1997) X-ray Diffraction and the Identification and Analysis of Clay Minerals, 2nd edition. Oxford University Press, New York, 378 pp.

Myrand D., Gillham R.W., Sudicky E.A., O'Hannesin S.F. \& Johnson R.L. (1992) Diffusion of volatile organic compounds in natural clay deposits: Laboratory tests. Journal of Contaminant Hydrology, 10, 159-177. DOI:10.1016/0169-7722(92)90027-C

Öman C.B. \& Junestedt C. (2008) Chemical characterization of landfill leachates - 400 parameters and compounds. Waste Management, 28, 1876-1891.

DOI:10.1016/j.wasman.2007.06.018

Ovadyahu D., Yariv S. \& Lapides I. (1998a) Mechanochemical adsorption of phenol by TOT swelling clay minerals. I. Thermo-IR-spectroscopy and X-ray study. Journal of Thermal Analysis, 51, 415-430.

Ovadyahu D., Yariv S., Lapides I. \& Deutsch Y. (1998b) Mechanochemical adsorption of phenol by TOT swelling clay minerals. II. Simultaneous DTA and TG study. Journal of Thermal Analysis, 51, 431-447.

Parfitt R.L.\& Mortland M.M. (1968) Ketone adsorption on montmorillonite. Soil Science Society of America, 32, 355-363.

Paing J., Guilbert A., Gagnon V. \& Chazarenc F. (2015) Effect of climate, wastewater composition, loading rates, system age and design on performances of French vertical flow constructed wetlands: A survey based on 169 full scale systems. Ecological Engineering, 80, 46-52. DOI: doi:10.1016/j.ecoleng.2014.10.029

Pelletier M., Michot L.J., Barrès O., Humbert B., Petit S. \& Robert J.L. (1999) Influence of $\mathrm{KBr}$ conditioning on the infrared hydroxyl-stretching region of saponites. Clay Minerals, 34, 439-445. DOI:10.1180/claymin.1999.034.3.05

Pironon J., Pelletier M., de Donato P., Mosser-Ruck R. (2003) Characterization of smectite and illite by FTIR spectroscopy of interlayer NH4+ cations. Clay Minerals, 38, 201-211. DOI: $10.1180 / 0009855033820089$

Pizzarello S., Schrader D.L., Monroe A.A. \& Lauretta D.S. (2012) Large enantiomeric excesses in primitive meteorites and the diverse effects of water in cosmochemical evolution. 
Proceedings of the National Academy Sciences of the United States of America, 109, 1194911954. DOI:10.1073/pnas.1204865109

Renou S., Givaudan J.G., Poulain S., Dirassouyan F. \& Moulin P. (2008) Landfill leachate treatment: Review and opportunity. Journal of Hazardous Materials, 150, 468-493. DOI: 10.1016/j.jhazmat.2007.09.077

Richards, S. \& Bouazza A. (2007) Phenol adsorption in organo-modified basaltic clay and bentonite. Applied Clay Science, 37, 133-142. DOI:10.1016/j.clay.2006.11.006

Saltzman S. \& Yariv S. (1975) Infrared study of sorption of phenol and p-nitrophenol by montmorillonite. Soil Science Society of America Journal, 39, 474-479.

Sim J.H., Seo H.J. \& Kim C.G. (2009) Physicochemical characteristics for adsorption of MTBE and cadmium on clay minerals. Environmental Earth Sciences, 59, 537-545. DOI: $10.1007 / \mathrm{s} 12665-009-0051-3$

Then, B.K.G. (1974) The Chemistry of Clay-Organic Reactions. Adam Hilger, London.

Van Nooten T., Diels L. \& Bastiaens L. (2008) Design of a multifunctional permeable reactive barrier for the treatment of landfill leachate contamination: laboratory column evaluation. Environmental Science and Technology, 42, 8890-8895. DOI:10.1021/es801704t

Vasudevan D., Arey T.A., Dickstein D.R., Newman M.H., Zhang T.Y., Kinnear H.M. \& Bader M.M. (2013) Nonlinearity of cationic aromatic amine sorption to aluminosilicates and soils: Role of intermolecular cation $-\pi$ interactions. Environmental Science and Technology, 47, 14119-14127. DOI:10.1021/es403389a

Viraraghavan T. \& de Maria Alfaro F. (1998) Adsorption of phenol from wastewater by peat, fly ash and bentonite. Journal of Hazardous Materials, 57, 59-70. DOI:10.1016/S03043894(97)00062-9

Watenphul A., Wunder B. \& Heinrich W. (2009) High-pressure ammonium-bearing silicates: implications for nitrogen and hydro-gen storage in the Earth's mantle. American Mineralogist, 94, 283-292. DOI: 10.2138/am.2009.2995

Ya, L. \& Bailey G.W. (2001) Sorption and abiotic redox transformation of nitrobenzene at the smectite-water interface. Journal of Colloid and Interface Science, 241, 142-153.

DOI:10.1006/jcis.2001.7735

Yapar S. \& Yilmaz M. (2005) Removal of phenol by using montmorillonite, clinoptilolite and hydrotalcite. Adsorption, 10, 287-298. DOI:10.1007/s10450-005-4814-1

Yariv S. (2003) Differential Thermal Analysis (DTA) in the Study of Thermal Reactions of Organo-Clay Complexes. Pp. 253-296 in: Natural and Laboratory-Simulated Thermal Geochemical Processes (R. Ikan, editor). Springer, Berlin.

Yariv S., Heller L., Sofer Z. \& Bodenheimer W. (1968) Sorption of aniline by montmorillonite. Israel Journal of Chemistry, 6, 741-756. 
Yariv S., Heller L. \& Kaufherr N. (1969) Effect of acidity in montmorillonite interlayers on sorption of aniline derivatives. Clays and Clay Minerals, 17, 301-308.

DOI:10.1346/CCMN.1969.0170507

Yariv S. \& Cross H. (2002) Organo-Clay Complexes and Interactions. Marcel Dekker, New York. $688 \mathrm{pp}$.

Yilmaz M. \& Yapar S. (2004) Adsorption properties of tetradecyl- and hexadecyl trimethylammonium bentonites. Applied Clay Science, 27, 223-228.

DOI:10.1016/j.clay.2004.08.001

Zadinelo I.V., Alves H.J., Moesch A. \& Colpini L.M.S. (2015) Influence of the chemical composition of smectites on the removal of ammonium ions from aquaculture effluent. Journal of Materials Science, 50, 1865-1875. DOI: 10.1007/s10853-014-8749-3

Zhang Z.Z., Low P.F., Cushman J.H. \& Roth C.B. (1990a) Adsorption and heat of adsorption of organic-compounds on montmorillonite from aqueous-solutions. Soil Science Society of America Journal, 54, 59-66.

Zhang, Z.Z., Sparks D.L. \& Pease R.A. (1990b) Sorption and desorption of acetonitrile on montmorillonite from aqueous-solutions. Soil Science Society of America Journal, 54, 351-356.

Zhang Z.Z., Sparks D.L. \& Scrivner N.C. (1990c) Acetonitrile and acrylonitrile sorption on montmorillonite from binary and ternary aqueous-solutions. Soil Science Society of America Journal, 54, 1564-1571.

Zhang P.C. \& Sparks D.L. (1993) Kinetics of phenol and aniline adsorption and desorption on an organo-clay. Soil Science Society of America Journal, 57, 340-345. 